18-20 December, 2020

Oxford, United Kingdom $11^{\text {th }}$ International Conference on

Humanities, Psychology \& Social Sciences

\title{
Anger association with racial attitudes toward Roma and Egyptians minorities in white Albanian students
}

\author{
Oriola Hamzallari ${ }^{1}$ \\ ${ }^{1}$ Aleksander Moisiu University, Albania
}

\begin{abstract}
.
Racial attitudes are biased attitudes based on race, and have a negative influence on racism. Emotions, and particularly anger regulation plays a role in the formation of racial attitudes. Anger is related with trait aggression and racism. Plus, research studies have continuously demonstrated the negative impact of racism on the well-being of ethnic minorities. Thus, this study investigated the association between anger in white Albanian students and their racial attitudes toward Roma and Egyptians minorities, to examine individual differences in racial attitudes. An online survey platform was designed and 273 students participated. The findings revealed a positive association between anger emotion and racial attitudes among Albanian students. The results are important in designing emotional regulation interventions that support positive interactions between the in-and-out groups, particularly for Roma an Egyptian minorities in Albania.
\end{abstract}

Keywords: Racial attitudes, Anger, Roma and Egyptians minorities, Albania

\section{Introduction}

Racism is a threat to equality between people with different ethnic and racial backgrounds. Recent research shows that people with higher racial attitudes have higher tendency for discrimination and lower levels of prosocial behaviors (Davis, 2020; DeCuir-Gunby, Allen, \& Boone, 2020). On the other hand, minority groups who daily face racial prejudices and discrimination have poorer health, social inferiority, and higher stress, and lower adjustment in life (Anderson \& Finche, 2017; Liu et al., 2019; Nadal et al., 2017; O'Keefe et al., 2015).

Recently, it was found that most people who have racial attitudes, may not be aware of their attitudes and discrimination behaviors by using subtle messages and microaggression (Banks et al., 2020). In one study, it was found that adults are more biased toward Black children versus White children, by falsely assuming that Black children are more often angry than White children (Halberstadt et al., 2020). Teachers who show tendencies of misperceived emotion of anger in Black children, are more prone to racial microaggressions in children (see Halberstadt et al., 2020). Further, Black adults are often perceived as angrier than Whites and with more emotional problems which again can be a source of racial microaggression (e.g. Cooper, 2018). Many studies have been carried out to understand how microaggression affect ethnic groups, but limited studies have examined individual differences of those who engage in racial microaggressive behaviors (Williams, 2020). In one recent study, Williams (2020, press) found out that microaggressions are forms of aggressive behaviors. Also, studies on aggressive behavior and individual differences related to trait aggression have been carried 
18-20 December, 2020

Oxford, United Kingdom

\section{$11^{\text {th }}$ International Conference on Humanities, Psychology \& Social Sciences}

out, indicating that higher trait aggression is related with higher aggressive behavior (e.g. Lawrence \& Hodgkins, 2009). Trait aggression is strongly associated with anger regulation (Anesti et al., 2009; Li \& Xia, 2020). In one study, Banks (2016) found out that anger unrelated to racial/ethnic groups, increased ethnocentrism and racial attitudes among Whites. Furthermore, general anger activated anti-black attitudes (Banks, 2014), but still it is unclear if anger can activate racial prejudices in other minority groups (Banks, 2016). This study is carried out in Albania, where the most marginalized minority groups are Roma and Egyptian communities and the social inclusion of these groups have been very challenging (NAPRE, 2015-2020). Most Roma and Egyptians have barriers in accessing services, they have poor living condition, low levels of education, low employment rates and face high levels of stigma, and many Roma and Egyptians children are faced with higher levels of subtle racial attitudes and racism, which many times is the reason why they drop out school (NAPRE, 2016-2020). The literature findings imply that trait anger may be a predictor of racial attitudes for Black minority groups but further studies are needed to understand other minority groups. Thus, in this study the focus is on Roma and Egyptians minority groups. In support of the research findings (Banks, 2014), it is hypothesized that higher anger is linked with higher racial attitudes towards Roma and Egyptians minority groups in Whites Albanian students.

\section{Methods}

\subsection{Participants and Procedures}

In this study, White Albanian students from public universities in Durres and Tirana filled in an online survey. In total, there were 274 students, 218 females and 55 males. The average age of students was $20.57(S D=2.7)$. Students were asked for their consent before filling in the surveys. The survey was mostly filled in by female students, and due to very low number of male students, another call to fill in the survey was launched only for male students.

The online google forms platform was open during the period of February until May 2020. The second call from late of March until May 2020 was launched only for male students. The average time to accomplish the task was about 15-20 minutes. Students could use any technological device that had internet for filling in the survey. In this paper, only data for racial attitudes and trait aggression are analyzed.

\subsection{Measures}

Racial attitudes. The instrument that was used to measure racial attitudes was Whites' attitudes toward blacks (ATB) (Brigham, 1993). The scale had 20 items, that measured social distance ("I would rather not have blacks live in the same apartment building I live in"), affective reactions to blacks (Interracial marriage should be discouraged to avoid "who-amI'? confusion which children feel), governmental policy (Black people are demanding too much too fast in their push for equal rights) and personal worry (I worry that in the next few years I may be denied my application for a job or a promotion because of preferential treatment given to minority group members). A Likert scale was used from 1 to 5 (1-not at all agree to 5-strongly agree). The scale was adapted to reflect the context of Albanian ethnic groups, the words Black was substituted with the words Roma and Egyptians. The Cronbach's alpha for the adapted scale was 0.74 . 
18-20 December, 2020

Oxford, United Kingdom $11^{\text {th }}$ International Conference on Humanities, Psychology \& Social Sciences

Anger. Anger levels were measured by using the subscale of anger taken from the Brief Aggression Questionnaire (Buss \& Perry, 1992). The Anger subscale has 7 items measuring trait anger and expression of anger (e.g. "I sometimes feel like a powder keg ready to explode", "I am an even-tempered person"). Students used a Likert Scale from 1 to 5 (1-not at all agree to 5-strongly agree) to measure their levels of anger. The Cronbach's alpha for the adapted anger subscale was .68, which is an acceptable internal reliability indicator.

\section{Results}

First, T-tests were conducted to see if there were any gender differences for racial attitudes and anger. Second, to determine the association between anger and racial attitudes, Pearson correlation was used. Then, a Simple Linear Regression was conducted to examine if trait aggression was a predictor of racial attitudes of White students. The data analyses were carried out by using SPSS 24 Package.

The T-tests results showed no significant differences in racial attitudes for males $(\mathrm{M}=62.9$, $\mathrm{SD}=6.7)$ and females $(\mathrm{M}=63, \mathrm{SD}=7) ; \mathrm{t}(272)=.108, \mathrm{p}=.914$, and no significant differences in anger for males $(\mathrm{M}=18.52, \mathrm{SD}=6.42)$ and females $(\mathrm{M}=19.07 ; \mathrm{SD}=6.74) ; \mathrm{t}(272)=.541, \mathrm{p}=.589$. There were no gender differences in racial attitudes and anger (see Table 1).

Pearson's $r$ correlations for anger and racial attitudes showed a positive link, $r(274)=.123, p$ $=$. 041. Then, a simple linear regression was performed to test if anger predicted racial attitudes in students. The regression results suggested that anger accounted in the amount of racial attitudes variability, $\mathrm{R} 2=.015, \mathrm{~F}(1,272)=4.201, \mathrm{p}=.041$. Even though the association is a weak one, it suggests that students with higher levels of anger are more prone to have higher racial attitudes (see Graph 1).

\section{Table 1}

\begin{tabular}{|c|c|c|c|c|c|}
\hline \multicolumn{6}{|c|}{ Descriptive Statistics } \\
\hline & Gender & $\mathrm{N}$ & Mean & $\begin{array}{c}\text { Std. } \\
\text { Deviation }\end{array}$ & $\begin{array}{l}\text { Std. Error } \\
\text { Mean }\end{array}$ \\
\hline \multirow[t]{2}{*}{ Anger } & Females & 219 & 19.0731 & 6.74803 & .45599 \\
\hline & Males & 55 & 18.5273 & 6.42003 & .86568 \\
\hline \multirow{2}{*}{$\begin{array}{l}\text { Racial } \\
\text { attitudes }\end{array}$} & Females & 219 & 63.0228 & 7.03037 & .47507 \\
\hline & Males & 55 & 62.9091 & 6.72550 & .90687 \\
\hline
\end{tabular}


18-20 December, 2020

Oxford, United Kingdom $11^{\text {th }}$ International Conference on

Humanities, Psychology \& Social Sciences

\section{Graph 1}

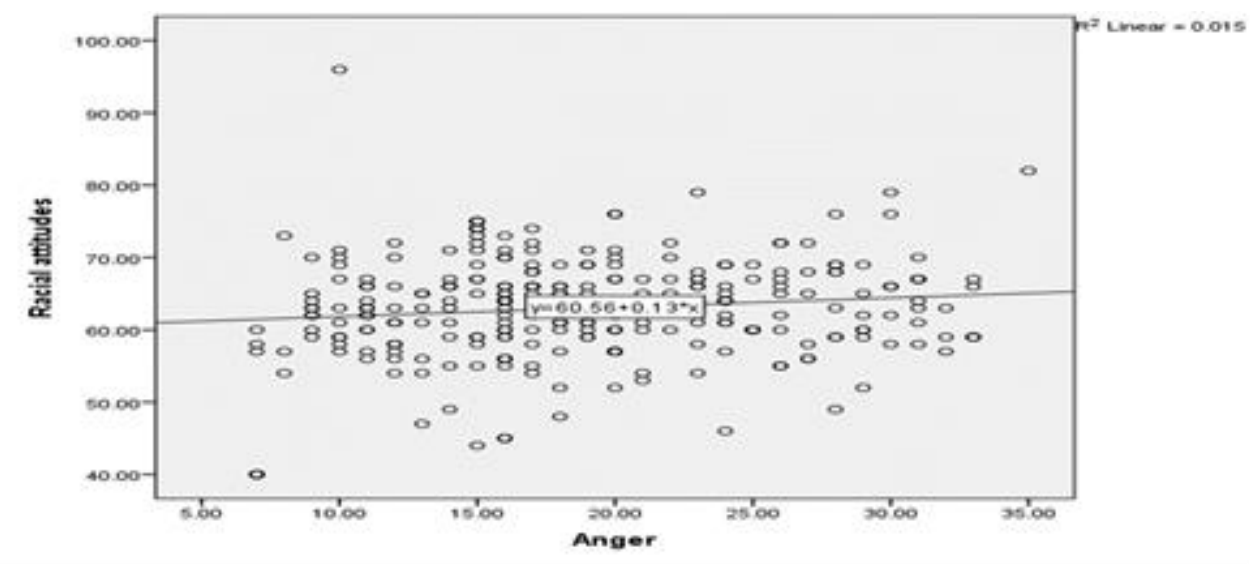

\section{Conclusion}

Most studies on racial attitudes and racism have investigated the effects of racial prejudices and racism on ethnic minority groups, but less studies have investigated individual differences of the in-group members that may be potential predictors for racial attitudes and racism. The few studies carried out, have revealed that anger may play a role in activating racial attitudes and racial behaviours. Thus, the current study contributed to extending the literature related to anger and racial attitudes in a new cultural context. The findings taken from the Albanian context showed that anger is associated with racial attitudes and influence the activation of racial attitudes toward Roma and Egyptian community groups. In regard to gender differences on anger and racial attitudes, the findings showed no significant association.

In the study of Banks (2016), anger levels and racial prejudices were strong when ethnocentrism was high, but when levels of ethnocentrism were low in the in-group members, and levels of anger were high, racial attitudes were low. In this study, the association between anger and racial attitudes was significant but not a strong association, and based on the Banks (2016), this weak but significant association may be interpreted on other predictors such as ethnocentrism levels of the in-group members. In the current study, levels of ethnocentrism were not measured but it is recommended in future studies to measure other potential factors such as ethnocentrism to explore the link between anger and racial attitudes. Also, other potential individual predictors that may influence the link between anger and racial attitudes may be related with personality traits, and further studies are needed to explore this link. Nevertheless, the results are important to design emotion regulation intervention supporting youth in-group members to understand the link between anger activation, racial attitudes and potential racial behaviours toward Roma and Egyptians minority groups.

In conclusion, this study indicated the relevance of emotions and particularly anger on racial attitudes in White Albanian students toward Roma and Egyptians community. Anger precede aggression toward ethnic minority groups and developing intervention to prevent racism on youth with high anger may be of great value for developing peaceful communities. 
18-20 December, 2020

Oxford, United Kingdom $11^{\text {th }}$ International Conference on Humanities, Psychology \& Social Sciences

\section{Acknowledgment}

The author of this study acknowledges the huge contributions of students that filled in the surveys.

\section{References}

Anesti, M.D., Anestis, J.C., Selby, E.A., \& Joiner, T.E. (2009). Anger rumination across forms of aggression. Personality and Individual Differences, 46 (2), 192-196.

Anderson, K.F., \& Finch, J.K. (2017). The role of racial microaggressions, stress, and acculturation in understanding Latino health outcomes in the USA. Race and Social Problems, 9(3), 218-233.

Banks, B., Adams, D., Williams, C., \& Pina, D. (2020). Preliminary Investigation of Efforts to Improve Awareness of Racial Microaggressions on Campus. Journal of Underrepresented \& Minority Progress, 4(1), 20-43.

Banks, A. J. (2014). Anger and racial politics: The emotional foundation of racial attitudes in America. New York: Cambridge University Press

Banks, A.J. (2016). Are Group Cues Necessary? How Anger Makes Ethnocentrism Among Whites a Stronger Predictor of Racial and Immigration Policy Opinions. Political Behavior, 38(3), 635-657.

Brigham, J. C. (1993). College students' racial attitudes. Journal of Applied Social Psychology, 23(23), 1933-1967.

Buss, A. H., \& Perry, M. (1992). The Aggression Questionnaire. Journal of Personality and Social Psychology, 63(3), 452-459.

Cooper, B. C. (2018). Eloquent rage: A Black feminist discovers her superpower. New York, NY: St. Martins Press.

Davis, A. N. (2020). Considering Racial Attitudes and Empathic Concern as Predictors of Prosocial Behaviors Among Emerging Adults. Race and Social Problems, 12(3), 279-287.

DeCuir-Gunby, J. T., Allen, E. M., \& Boone, J. K. (2020). Examining pre-service teachers' color-blind racial ideology, emotion regulation, and inflexibility with stigmatizing thoughts about race. Contemporary Educational Psychology, 60, 101836.

Halberstadt, A. G., Cooke, A. N., Garner, P. W., Hughes, S. A., Oertwig, D., \& Neupert, S. D. (2020, in Press). Racialized emotion recognition accuracy and anger bias of children's faces. Emotion. https://psycnet.apa.org/doi/10.1037/emo0000756

Lawrence, C., \& Hodgkins, E. (2009). Personality influences on interpretations of aggressive behavior: The role of provocation sensitivity and trait aggression. Personality and Individual Differences, 46(3), 319-324.

Li, R., \& Xia, L.-X. (2020, in Press). The mediating mechanisms underlying the longitudinal effect of trait anger on social aggression: Testing a temporal path model. Journal of Research in Personality, 88, 104018. https://doi.org/10.1016/j.jrp.2020.104018 


\section{8-20 December, 2020}

Oxford, United Kingdom $11^{\text {th }}$ International Conference on Humanities, Psychology \& Social Sciences

Liu, W.M., Liu, R.Z., Garrison, Y.L., Kim, J.Y.C., Chan, L., Ho, Y.C.S.H., \& Yeung, C.W. (2019). Racial trauma, microaggressions, and becoming racially innocuous: The role of acculturation and white supremacist ideology. American Psychologist, 74(1), 143-155.

Nadal, K.L., Griffin, K.E., Wong, Y., Davidoff, K.C., \& Davis, L.S. (2017). The injurious relationship between racial microaggressions and physical health: Implications for social work. Journal of Ethnic \& Cultural Diversity in Social Work, 26(1-2), 6-17.

NAPRE (2016-2020). National Action Plan for Integration of Roma and Egyptians in the Republic of Albania. Available: https:/www.rcc.int/romaintegration2020/docs/7/thenational-action-plan-for-integration-of-roma-and-egyptians-2016-2020--albania

O’Keefe, V.M., Wingate, L.R., Cole, A.B., Hollingsworth, D.W., \& Tucker, R.P. (2015). Seemingly harmless racial communications are not so harmless: Racial microaggressions lead to suicidal ideation by way of depression symptoms. Suicide and LifeThreatening Behavior, 45(5), 567-576.

Williams, M. T. (2020, in Press). Microaggressions Are a Form of Aggression. Behavior Therapy. https://doi.org/10.1016/j.beth.2020.09.001 